\title{
The effect depression levels in midwives have on burnout and their level of job satisfaction
}

\author{
Sümeyye Altiparmak ${ }^{1}$, Ayşe N. Yilmaz ${ }^{2}$
}

\begin{abstract}
INTRODUCTION This study aimed to determine the effect of depression levels in midwives on burnout and job satisfaction.

METHODS The sample of this descriptive study consisted of 322 midwives working in a province located in the eastern region of Turkey. Data were collected by using the Personal Information Form, Beck Depression Inventory (BDI), Maslach Burnout Inventory (MBI), and Minnesota Job Satisfaction Questionnaire (MJSQ) Short Form.

RESULTS The rate of midwives experiencing depression was found to be $9.6 \%$. The mean score of MJSQ was $64.59 \pm 13.29$, while the mean scores for the sub-dimensions of MBI were: emotional burnout $18.57 \pm 6.65$, decrease in sense of personal accomplishment $21.65 \pm 3.93$, and depersonalization $6.25 \pm 3.86$. It was found that midwives who did not experience depression (90.4\%) had a higher level of job satisfaction and a higher sense of personal accomplishment $(p<0.05)$. On the other hand, midwives experiencing depression (9.6\%) had higher levels of emotional exhaustion and depersonalization. It was found that there was a negative weak relationship between BDI and job satisfaction and personal accomplishment, and a positive weak relationship between BDI and emotional exhaustion $(p<0.05)$.

conclusions It was determined that midwives with depression have lower levels of job satisfaction and personal success, and experience emotional exhaustion more frequently. In addition, it was observed that as the level of depression decreased, job satisfaction and personal success increased significantly, whereas emotional exhaustion decreased.
\end{abstract}

\section{AFFILIATION \\ 1 Department of Midwifery, Faculty of Health Sciences, Inonu University, Malatya, Turkey 2 Department of Midwifery, Faculty of Health Sciences, Firat University, Elazığ, Turkey}

\section{CORRESPONDENCE TO}

Sümeyye Altiparmak. Department of Midwifery, Faculty of Health Sciences, Inonu University, Malatya, Turkey. E-mail: sumeyye. kandemir@inonu.edu.tr ORCID ID: https://orcid. org/0000-0002-4759-1210

\section{KEYWORDS \\ depression, emotional exhaustion, midwife, job satisfaction, exhaustion \\ $\checkmark$ \\ Received: 14 December 2020 Revised: 15 May 2021 \\ Accepted: 17 May 2021}

\section{INTRODUCTION}

The emotional state that occurs in the face of life events that are undesirable or disappointing in healthy individuals is called depression ${ }^{1}$. In addition, depression is much more severe than emotional reactions such as distress and grief, and negatively affects the life of the individual by disrupting their vital functions. It can also disturb sleep and appetite; tiredness and poor concentration are common ${ }^{1,2}$. Depression is common in society, in all age groups and various personal and vital factors including age, gender, socioeconomic level, education level, and marital status, may pose a risk for depression ${ }^{2-7}$.

Depression also affects the level of burnout in individuals. Burnout is defined as depersonalization, emotional exhaustion and low sense of personal accomplishment, observed in individuals who have an intense relationship with other people due to their profession ${ }^{8}$. Burnout is a condition that can be affected by sociodemographic and occupational variables ${ }^{9}$. Burnout syndrome is seen as a first-degree threat for individuals who work in intense conditions, and individuals with this syndrome may feel without energy to start a new day compared to other individuals ${ }^{8,10}$.

Especially in individuals working as healthcare professionals, intense workload, providing care for serious and terminally ill patients, experiencing problems in sharing duties in the workplace, shift hours, disruption of sleep, and economic problems cause work-related stress and tension ${ }^{1-13}$. Witnessing or hearing about a traumatic event may have a traumatic effect similar to experiencing that event directly. Frequent encounters with traumatic events may also cause burnout and various mental problems in healthcare professionals ${ }^{12}$. Burnout syndrome experienced in professional life leads to problems such as an increase 
in depressive complaints, impaired quality of life, fatigue, sleep disorders, irritability, decreased job satisfaction, and disruption of professionalism. It has been reported that depression is more common in healthcare professionals than in the general public ${ }^{11-14}$.

Midwives provide some of the most important healthcare services including prenatal care, delivery and postnatal care with strategies for the development, improvement and protection of maternal and child health. In addition, midwives play an important role in reducing maternal and infant mortality ${ }^{15-17}$. The fact that healthcare services focus on people, and require very careful and continuous work, makes the job satisfaction for those working in this field even more important. Midwives' potential for providing qualified service in the field of healthcare depends on their job satisfaction as well as their professional scientific knowledge. Job satisfaction is also affected by individual, organizational, and environmental factors ${ }^{10,15,16,18}$. Midwives who experience dissatisfaction with their job may experience situations such as continuous complaint, feeling dismissal and indifference towards the job, and feel hopeless regarding the future of the profession. In addition, job dissatisfaction may result in slowdown or shutdown of services, decrease in work efficiency, significant absenteeism and delays, resignation, incompatibility between peers, and non-compliance with business rules and work orders ${ }^{15,16,18}$. This situation is also emphasized by the intrinsic and extrinsic sources of motivation that affect Herzbergs' job satisfaction ${ }^{19}$.

It is thought that job satisfaction of midwives is necessary for both the happiness of midwives and the improvement of quality of the services provided by them, and therefore the health level of society. If job satisfaction levels of midwives are determined and the reasons for the decrease are defined, activities that will increase job satisfaction can be planned and implemented ${ }^{15,18}$. For this purpose, this study aims to evaluate the effect of depression levels in midwives on burnout and job satisfaction.

\section{METHODS}

\section{Study design and sample}

This study aimed to determine the effect of depression levels in midwives on burnout and job satisfaction, qualitatively. The study was conducted on midwives working in all hospitals and family health centers in a province in the east of Turkey between 15 and 30 October 2020. A total of 553 midwives work in the institutions where the study was conducted. A total of 322 midwives who voluntarily accepted to participate in the study were included in the study. Midwives working in family and community health centers work in the day shift between 08:00-16:00, and midwives working in the hospital work either a day shift 08:00-16:00 or night shift 16:00-08:00. All midwives work at least 40 hours per week.

\section{Inclusion criteria}

The midwives who have been working in midwifery for at least 1 year in order to have work experience, working actively at the time of the study, those who were without any diagnosed psychiatric health problem, and who have internet access and volunteered for the study were included in the study.

\section{Exclusion criteria}

The midwives who did not respond to all questionnaires were excluded from the study.

\section{Data collection tools}

Personal Information Form with Beck Depression Inventory (BDI), Maslach Burnout Inventory (MBI) and Minnesota Job Satisfaction Inventory Short Form, which are frequently used in professional studies, were used to collect data.

\section{Personal information form}

The personal information form was prepared by the researchers in line with the literature and consists of 14 questions, including 3 questions about the sociodemographic characteristics (age, educational status, income status) of the midwives and 11 questions about the job (years in the profession, duration, and type of work, etc. ${ }^{17,20}$. This form was created by the researchers.

\section{Beck Depression Inventory (BDI)}

Beck Depression Inventory was developed by Beck in 1961. BDI is used to determine the risk for depression and to measure the level of depressive symptoms and the changes in severity ${ }^{21}$. The validity and reliability studies were conducted in Turkish by Hisli in $1989^{22}$. It consists of 21 self-evaluation items scored between 0 and 3 . Each item determines a behavioral pattern specific to depression in the last week. The total score that can be obtained from the scale varies between 0 and 63 . The cutoff score was accepted as 17 . Scores $\geq 17$ are accepted as having depression symptoms. Cronbach's alpha reliability coefficient of the scale was found to be $0.80^{22}$. In the present study, the Cronbach's alpha reliability coefficient of the scale was 0.84 .

\section{Maslach Burnout Inventory (MBI)}

Maslach Burnout Inventory (MBI) was developed by Maslach and Jackson in $1981^{23}$. The inventory consists of 3 subdimensions including emotional burnout (EB), personal accomplishment (PA), and depersonalization (D). The scale includes a total of 22 items; 9 items evaluating emotional burnout, 8 items evaluating personal success, and 5 items evaluating depersonalization. The inventory was adapted to Turkish by Ergin ${ }^{24}$ in 1992 and some changes were made in the inventory. While the items in the original inventory were answered on a 7-point Likert scale, it was rearranged to 5 points in the Turkish version, since it was observed that a 7-point scale was not suitable for Turkish culture. The answers include: O Never, 1 Very rare, 2 Sometimes, 3 Most of the time, and 4 Always. The total score of $\mathrm{MBI}$ is obtained by the sum of the sub-dimension scores; EB and D sub-dimensions are scored as defined above, while PA sub-dimension is scored reversely (never: 4; always: 0 ). Therefore, low scores obtained from PA sub-dimension 
indicate burnout whereas high scores from the EB and D sub-dimensions indicate burnout. Cronbach's alpha reliability coefficients were 0.83 for EB, 0.72 for Depersonalization, and 0.67 for decreased sense of $\mathrm{PA}^{24}$. In the present study, Cronbach's alpha reliability coefficients of the scale were $0.87,0.75$, and 0.67 , respectively.

\section{Minnesota job satisfaction questionnaire - short form}

The short form of the Minnesota Job Satisfaction Questionnaire was developed by Davis ${ }^{25}$. The Turkish validity and reliability study of the scale was conducted by Ozdayi ${ }^{26}$ in 1991 and the items related to internal and external attitude factors in the long form were combined into a 20item scale ${ }^{26}$. The scale has two sub-dimensions including internal job satisfaction and external job satisfaction.

Internal job satisfaction sub-dimension consists of 12 items that include the expressions 'activity, freedom, change, moral values, helping others, authority, using their abilities, responsibility, creativity, appreciation, success, and respect in the society'.

External job satisfaction sub-dimension consists of 8 items that include the expressions "promotion opportunity, institutional policy and practices, colleagues, working conditions, salary, manager's management approach, manager's technical support, and job guarantee'.

The items are answered on a 5-point Likert type scale, and the answers given to each item are scored between 1 and 5, where 1 represents 'Not satisfactory at all' and 5 represents 'Very satisfactory'. The higher scores indicate higher job satisfaction. The Cronbach alpha reliability coefficient for the internal consistency of the scale was $0.86^{26}$. In the present study, Cronbach's alpha reliability coefficient of the scale was 0.92 .

\section{Data collection}

Before the data collection process, the responsible midwives, in the hospitals and family health centers where the study was conducted, were reached. The questionnaire forms prepared were sent online to the phones of the responsible midwives and the questionnaire forms were requested to be sent to the social media network of all midwives working in the clinic. The midwives who accepted to participate in the study were asked to fill in the questionnaire, which took approximately 5-10 minutes.

\section{Statistical analysis}

The data were evaluated by using the SPSS 20.0 package program. In the statistical analysis Cronbach's alpha, Pearson correlation analysis, and independent samples t-test, were used. The results were expressed as percentage distribution, mean and standard deviation. Results were evaluated at $95 \%$ confidence interval and a value of $\mathrm{p}<0.05$ was considered to be statistically significant.

\section{RESULTS}

The mean age of midwives was $37.82 \pm 9.07$ years (range: 20-58), 50.3\% of midwives were undergraduate/university graduates, and $57.5 \%$ were equal to their income and expenses, $50.6 \%$ worked in the provincial state hospital, $46.9 \%$ for $1-10$ years, and $72.4 \%$ worked 40 hours a week. Midwives worked in an area related to obstetrics for an average of $9.14 \pm 6.23$ years and $40.7 \%$ thought that the number of midwives in the service they work is not sufficient. In all, $89.1 \%$ of midwives stated that they liked their profession, $76.4 \%$ chose the unit they work willingly, $67.7 \%$ chose their profession willingly, $82.3 \%$ found their profession suitable for them, and $47.2 \%$ of the midwives stated that they were members of the trade union related to the profession (Supplementary file).

Depression status of midwives according to the Beck Depression Scale cut-off score is given in Table 1 . While $90.4 \%$ of midwives were non-depressed, scores $\geq 17$ points on the scale, $9.6 \%$ were depressed (Table 1).

Table 2 shows the range of possible scores in MJSQ and $\mathrm{MBI}$ sub-dimensions, the range of scores attained by the midwives, and the distribution of the mean scores. The range and mean scores attained by the midwives were: MJSQ 20-98 with mean 64.59 \pm 13.29 ; MBI emotional burnout sub-dimension 0-35 with mean $18.57 \pm 6.65$; $\mathrm{MBI}$ decrease in the sense of personal accomplishment sub-dimension

\section{Table 1. Depression status of midwives according to the cut-off score of the Beck Depression Inventory $(N=322)$}

\begin{tabular}{l|c|c|c|}
\hline Beck Depression Inventory & Cut-off score & $\boldsymbol{n}$ & $\%$ \\
\hline Depressed & $<17$ & 31 & 9.6 \\
\hline Non-depressed & $\geq 17$ & 291 & 90.4
\end{tabular}

Table 2. Range of possible scores in MJSQ and MBI sub-dimensions, the attained scores of the midwives, and the distribution of the mean scores $(\mathrm{N}=322)$

\begin{tabular}{|l|c|c|c|}
\hline Scales & Range of possible scores & Range of attained scores & Mean \pm SD \\
\hline MJSQ & $0-100$ & $20-98$ & $64.59 \pm 13.29$ \\
\hline MBI sub-dimensions & & & $18.57 \pm 6.65$ \\
\hline Emotional burnout & $0-36$ & $0-35$ & $21.65 \pm 3.93$ \\
\hline Personal accomplishment & $0-32$ & $10-32$ & $6.25 \pm 3.86$ \\
\hline Depersonalization & $0-20$ & $0-18$ &
\end{tabular}

SD: standard deviation. MJSQ: Minnesota Job Satisfaction Questionnaire. MBI: Maslach Burnout Inventory. 


\section{Table 3. Comparison of the mean scores of MJSQ and sub-dimensions of MBI according to the depression status of midwives ( $N=322)$}

\begin{tabular}{|c|c|c|c|}
\hline Scales & $\begin{array}{l}\text { Depressed } \\
\text { Mean } \pm S D\end{array}$ & $\begin{array}{c}\text { Non-depressed } \\
\text { Mean } \pm S D\end{array}$ & $t$-test ${ }^{*}$ and $p^{* *}$ \\
\hline MJSQ & & $65.62 \pm 12.83$ & $\mathrm{t}=4.402 \mathbf{p}=\mathbf{0 . 0 0 0}$ \\
\hline \multicolumn{4}{|l|}{ MBI sub-dimensions } \\
\hline Emotional burnout & $22.09 \pm 6.68$ & $18.19 \pm 6.54$ & $t=-3.147 p=0.002$ \\
\hline Personal accomplishment & $19.61 \pm 4.19$ & $21.87 \pm 3.84$ & $t=3.084 \mathbf{p}=\mathbf{0 . 0 0 2}$ \\
\hline Depersonalization & $6.77 \pm 4.50$ & $6.19 \pm 3.79$ & $t=-0.792 p=0.429$ \\
\hline
\end{tabular}

*Independent samples t-test. ${ }^{* *} \mathrm{p}<0.001$. MJSQ: Minnesota Job Satisfaction Questionnaire. MBI: Maslach Burnout Inventory.

Table 4. The relationship between of the mean total scores of BDI, MJSQ, and sub-dimensions of $\mathrm{MBI}$

\begin{tabular}{lcc} 
Scales & $\boldsymbol{r}^{*}$ & $\boldsymbol{p}$ \\
\hline $\mathrm{BDI}$ - MJSQ & -0.297 & $0.000^{* *}$ \\
\hline $\mathrm{BDI}$ - emotional burnout & 0.297 & $0.000^{* *}$ \\
BDI - personal accomplishment & -0.175 & $0.002^{* * *}$ \\
BDI - depersonalization & 0.099 & 0.076
\end{tabular}

*Pearson correlation analysis. ${ }^{* *} \mathrm{p}<0.001 .{ }^{* * *} \mathrm{p}<0.05$. BDI: Beck Depression Inventory. MJSQ: Minnesota Job Satisfaction Questionnaire. MBI: Maslach Burnout Inventory.

10-32 with mean 21.65 \pm 3.93 ; $\mathrm{MBI}$ depersonalization subdimension 0-18 with mean 6.25 \pm 3.86 .

The comparison of the mean scores of midwives in the sub-dimensions of MJSQ and MBI according to their depression experience is given in Table 3. It was found that midwives who did not experience depression experienced higher levels of job satisfaction. Midwives with depression attained higher scores in the $\mathrm{MBI}$ sub-dimensions of emotional exhaustion and depersonalization $(t=-3.147$, $\mathrm{p}=0.002$ and $\mathrm{t}=-0.792 \mathrm{p}=0.429$, respectively). Midwives who did not experience depression attained higher scores in the $\mathrm{MBI}$ sub-dimension of decrease sense of personal accomplishment ( $t=3.084, p=0.002)$.

The relationship between mean total scores of BDI, MJSQ, and sub-dimensions of MBI of midwives are given in Table 4. There was a statistically weak and negatively significant relationship between the BDI and the MJSQ mean scores, and as the level of depression increased, job satisfaction decreased significantly ( $r=-0.297 ; p=0.000)$. There was a statistically positive and weakly significant relationship between the BDI mean score and mean score attained from the emotional burnout sub-dimension, and as the level of depression increased, emotional burnout increased significantly $(r=0.297 ; p=0.000)$. There was a statistically negative weakly significant correlation between the BDI mean score and the mean score attained from the sub-dimension of decreased personal accomplishment, and as the level of depression increased, the sense of personal accomplishment decreased significantly $(r=-0.175$; $p=0.000)$. There was a statistically weak and insignificant relationship between the BDI mean score and the mean score attained from the depersonalization sub-dimension, and as the level of depression increased, depersonalization decreased significantly $(r=-0.175 ; p=0.076)$ (Table 4).

\section{DISCUSSION}

It our study, $50.3 \%$ of the midwives were undergraduate, $50.6 \%$ were working in the provincial state hospital and $87.0 \%$ were working in the midwife position. In the study of Ucucu $^{27}$, it was stated that $59.5 \%$ of midwives had an undergraduate and $72.2 \%$ were working in state and university hospitals. In the study of Baskaya ${ }^{28}$, it was found that $70.4 \%$ of midwives had an undergraduate degree. In our study, $72.4 \%$ of midwives were working 40 hours per week and $40.7 \%$ thought that the number of midwives in the service they work was not sufficient. In the study of $U_{c u c u}{ }^{27}$, it was found that $49.8 \%$ of midwives work 40 hours a week. In the study of Baskaya ${ }^{28}$, it was reported that $69.3 \%$ of the midwives thought that the number of midwives was not sufficient.

In the literature, it has been stated that midwives who chose their profession willingly have higher levels of job satisfaction $^{29}$. In our study, $89.1 \%$ of midwives liked their job, $67.7 \%$ had chosen their profession willingly, and $76.4 \%$ had chosen the unit they work willingly. In the study of Baskaya ${ }^{28}$, when midwives were asked why they had chosen the midwifery profession, $26.4 \%$ had chosen midwifery because they liked it, and $28.2 \%$ had chosen it because their families wanted it. Similar to our results, in the study of $\mathrm{Ucucu}^{27}, 70.7 \%$ of the midwives preferred the unit they worked in. In the study of Toker et al. ${ }^{9}, 60.3 \%$ of midwives stated that they liked their profession, $66.2 \%$ wanted to improve themselves, and $61.8 \%$ chose their profession willingly. In the same study, $47.1 \%$ of midwives stated that they chose the profession because of the easy job opportunity. In our study, $82.3 \%$ of midwives stated that they thought their profession was suitable for them. However, in the study of Ucucu ${ }^{27}$, this rate was $69.8 \%$. This difference is thought to be related to personal variables.

In our study, the rate of midwives who scored higher than 17 points, which is the cut-off point of BDI, namely those who were not experiencing depression was $90.4 \%$, while the rate of those experiencing depression was 9.6\%. In the study of Yildirim and Hacihasanoglu ${ }^{11}$, on healthcare professionals, 
the rate of those experiencing depression was $16.4 \%$. In a study conducted on midwives in the United Kingdom, it was found that one-third of the participants scored moderate or above in terms of depression, anxiety and stress ${ }^{30}$. In the study of Creedy ${ }^{31}$, on Australian midwives, it was reported that approximately $20 \%$ of midwives experienced significant depression, anxiety and stress symptoms.

In our study, midwives who did not experience depression experienced a higher level of job satisfaction. In the study of Creedy ${ }^{31}$, the midwives exhibited high levels of personal and work-related burnout. This situation shows that midwives were affected by burnout, depression, anxiety and stress symptoms frequently in their private and professional lives.

The mean score of midwives on MJSQ was 64.59 \pm 13.29 . In our study, job satisfaction of midwives was at a medium level. It is thought that midwives cannot achieve a high level of job satisfaction due to factors including workload, insomnia, fatigue, intense stress, and the COVID-19 pandemic. In the study of $\mathrm{Ucucu}^{27}$ on midwives, the mean MJSQ score was $56.21 \pm 12.47$. Tekin et al. ${ }^{32}$ in their study stated that the mean MJSQ score of midwives and nurses working in primary healthcare in Cankiri was 61.81 \pm 12.79 . In the study of Erdogan ${ }^{33}$, the mean MJSQ score of nurses was $82.07 \pm 6.15$ and the job satisfaction level was high. Our study is compatible with the literature. In addition, in our study, there was a weak negative significant relationship between the $\mathrm{BDI}$ and $\mathrm{MBI}$ mean scores, and as the level of depression increased, job satisfaction decreased significantly.

The effects of job satisfaction and motivational factors on the efficiency and effectiveness of midwives directly influences the quality of health care ${ }^{33}$. Midwifery is one of the occupational groups that closely deal with the physical, emotional and social problems of the people they serve. While dealing with these problems, midwives will be able to feel the needs of their own physical, social and psychological health. As a matter of fact, the tension resulting from the decrease in job satisfaction as a result of not meeting the needs can negatively affect the mental health of individuals and cause burnout ${ }^{34}$. Similar to this study, Taycan et al. ${ }^{35}$ found that depression and burnout rates were lower in those who were generally satisfied with their job. On the other hand, Creedy ${ }^{31}$ suggested that future studies should evaluate midwives to determine whether occupational burnout or personal factors affecting women cause or contribute to the development of depression.

In our study, we determined that there was a statistically significant weak positive correlation between the mean BDI and the emotional burnout sub-dimension of the MBI scores and as the depression level increased, emotional burnout increased significantly. In the study of Taycan et al. ${ }^{35}$, it was found that there was a positive significant correlation between the mean BDI and the emotional burnout sub-dimension scores of the nurses $(r=0.343 ; p<0.01)$. In the study of Unver et al. ${ }^{34}$, it was determined that as the level of tension due to work increases, the level of emotional exhaustion and depersonalization increases significantly. In the study of Yildirim and Hacihasanoglu $\mathrm{u}^{11}$ on healthcare workers, a weak positive correlation was found between the mean BDI and the emotional burnout sub-dimension scores ( $p<0.001$ ).

In our study, there was a weak negative significant correlation between the mean BDI and the decrease in personal accomplishment sub-dimension of MBI scores, and as the depression level increased, the sense of personal accomplishment decreased significantly. Consistent with our study, Taycan et al. ${ }^{35}$ reported that a significant negative correlation was found between the mean BDI and decrease in personal accomplishment sub-dimension scores of nurses $(r=$ $-0.151 ; p<0.01)$. In the study of Yildirim and Hacihasanoglu $u^{11}$ on healthcare professionals, a statistically weak positive relationship was found between the mean $\mathrm{BDI}$ and decrease in personal accomplishment sub-dimension of MBI $(p<0.001)$.

\section{Strengths and limitations}

Our study has some strengths and limitations. There is no study examining depression, burnout and job satisfaction on midwives in the literature review. This is the strongest aspect of this work. Inclusion of midwives working in all family health centers and hospitals at the place where the study was conducted is another strength. But, only $60 \%$ of the midwives were reached and this is a limitation of the study. The criterion of 'Doing the midwifery profession for at least 1 year' among the recruitment criteria may have resulted in this. The work is also limited to midwives working in a province in eastern Turkey. For this reason, the results obtained from the study cannot be generalized to all midwives in Turkey.

\section{CONGLUSIONS}

Midwives with depression have lower levels of job satisfaction and personal success and experience more emotional exhaustion. In addition, it was seen that as the level of depression increased, job satisfaction and personal success increased significantly, whereas emotional exhaustion decreased. Reducing the depression and burnout levels of midwives, who have important roles in terms of family and public health, and increasing their job satisfaction levels will increase both their happiness and the quality of the service provided, and the health level of the family and society will increase. Factors that cause depression and burnout should be determined in midwives, and interventions and support systems should be planned for these factors.

\section{REFERENCES}

1. Depression. Health Topics. World Health Organization. Accessed May 10, 2020. https://www.who.int/healthtopics/depression

2. Kavakçı Ö, Bilici M, Çam G, Ülgen M. Trabzon ilinde elli beş yaşından büyüklerde depresyon ve bilişsel bozulma yaygınlığı. Prevalence of depression and cognitive impairment in old age in Trabzon. Article in Turkish. Anadolu Psikiyatri Dergisi. 2011;12(4):258-265. Accessed May 15, 2021. http://search.ebscohost. com/login.aspx? direct $=$ true $\& \mathrm{db}=$ asn $\& A N=74612882$ \&site=ehost-live

3. Keskin A, Ünlüoğlu i, Bilge U, Yenilmez Ç. The Prevalence of Psychiatric Disorders Distribution of Subjects Gender and its Relationship with Psychiatric 
Help-Seeking. Noro Psikiyatr Ars. 2013;50(4):344-351. doi:10.4274/npa.y6522

4. Yildirim E, Tan MN. Depresyonda Risk Faktörleri, Belirti ve Bulgular. Risk factors, signs and symptoms in depression. Article in Turkish. Turkiye Klinikleri Family Medicine - Special Topics. 2017;8(1):15-20. Accessed May 15, 2021. https://www.turkiyeklinikleri. com/article/en-depresyonda-risk-faktorleri-belirti-vebulgular-77651.html

5. Gournellis R, Oulis P, Howard R. Psychotic major depression in older people: a systematic review. Int J Geriatr Psychiatry. 2014;29(8):784-796. doi:10.1002/gps.4065

6. Nietola M, Huovinen H, Heiskala A, et al. Early childhood and adolescent risk factors for psychotic depression in a general population birth cohort sample. Soc Psychiatry Psychiatr Epidemiol. 2020;55(9):11791186. doi:10.1007/s00127-020-01835-7

7. Heslin M, Desai R, Lappin JM, et al. Biological and psychosocial risk factors for psychotic major depression. Soc Psychiatry Psychiatr Epidemiol. 2016;51(2):233245. doi:10.1007/s00127-015-1131-1

8. Maslach C, Leiter MP. Understanding the burnout experience: recent research and its implications for psychiatry. World Psychiatry. 2016;15(2):103-111. doi:10.1002/wps.20311

9. Toker E, Turan Z, Seçkin Z. Bir Hastanede Çalışan Ebelerin Mesleki Örgütlenme Durumu, İş Doyumu ve Tükenmişlik Düzeylerinin Belirlenmesi. The determination of professional organization status, job satisfaction and burnout levels of midwives who work at a hospital. Article in Turkish. Sağlık ve Toplum. 2020;20(1):8897. Accessed May 15, 2021. https://ssyv.org.tr/ wp-content/uploads/2020/02/11-Bir-HastanedeÇalışan-Ebelerin-Mesleki-Örgütlenme-Durumu-iş̧Doyumu-ve-Tükenmişlik-Düzeylerinin-Belirlenmesi.pdf

10. Kaya ZA. Antalya Emniyet Müdürlüğü Hassas Bölgeleri Koruma Şube Müdürlüğü Personelinde Tükenmişlik Sendromu Üzerine Bir Çalişma. A Study on the BurnOut Syndrome observed among the personnel of the Sensitive Areas Protection Unit of the Antalya Police Force. Article in Turkish. Hikmet Yurdu - Düşünce - Yorum Sosyal Bilimler Araştırma Dergisi. 2014;7(13):229-250. doi:10.17540/hy.v7i13.252

11. Yildirim A, Hacıhasanoğlu R. Saglik calisanlarinda yasam kalitesi ve etkileyen degiskenler. Quality of life and effective variables among health care professionals. Article in Turkish. Psikiyatri Hemşireliği Dergisi. 2011;2(2):61-68. Accessed May 15, 2021. https://jag. journalagent.com/phd/pdfs/PHD_2_2_61_68.pdf

12. Karsavuran S. Sağlık Sektöründe Tükenmişlik: Ankara'daki Sağlık Bakanlığı Hastaneleri Yöneticilerinin Tükenmişlik Düzeyleri. Burnout in healthcare sector: Level of burnout level of the managers at the ministry of health hospitals in Ankara. Article in Turkish. Hacettepe Üniversitesi İktisadi ve İdari Bilimler Fakültesi Dergisi. 2014;32(2):133-165. doi:10.17065/huiibf.95124

13. Kalinkara V, Kalayci I. Yaşlıya Evde Bakım Hizmeti Veren
Bireylerde Yaşam Doyumu, Bakım Yükü ve Tükenmişlik. Life satisfaction, care burden and burnout of the individuals who have a caregiver service to the elderly at home. Article in Turkish. Yaşı Sorunları Araştırma Dergisi. 2017;10(2):19-39. Accessed May 15, 2021. https:// dergipark.org.tr/en/pub/yasad/issue/30342/311705

14. İçağasığlu ÇMA, Özbesler C. Hastanelerde Çalışan Sosyal Hizmet Uzmanlarında Tükenmişlik ve İş Doyumu. Burn-Out and Job Satisfaction of Social Workers in Hospitals. Article in Turkish. Başkent Üniversitesi Sağlık Bilimleri Fakültesi Dergisi. 2016;1(2):90-109. Accessed May 15, 2021. http://busbid.baskent.edu.tr/index.php/ busbid/article/view/45

15. Bilgin Z, Yaşar KM, Yeşilyurt G, Öztürk D. Ebelerde Örgütlenme ve iş Doyumunun Belirlenmesi. The organization in midwives and determination of job satisfaction. Article in Turkish. Sağlık Bilimleri ve Meslekleri Dergisi. 2017;4(2):105-110. doi:10.17681/hsp-dergisi.287522

16. Ağapınar SS, Güler H. Ağrı Illinde Çalışan Ebelerin Tükenmişlik Düzeylerinin İş Doyumları ve Empatik Eğilimleri Üzerine Etkisi. The Effects of the Levels of Burnout Midwives Working in Ağrı on the Job Satisfaction and Empathic Tendencies of Them. Article in Turkish. TAF Prev Med Bull. 2014;13(2):141-150. doi:10.5455/pmb.1-1362145578

17. Karakuş Ç. Çalışma Hayatında İş Tatmini ve İş Stresi: Özel Bir Hastanede Çalışan Hemşireler Üzerine Bir Araştırma. Job satısfactıon and work stress ın workıng lıfe: In a private hospital nurses on reresearch. Article in Turkish. Kırşehir Ahi Evran Üniversitesi İktisadi ve İari Bilimler Fakültesi Dergisi, 2019;3(1): 92-104. Accessed May 15, 2021. https://dergipark.org.tr/en/ $\mathrm{pub/aeuiibfd/issue/46274/565253}$

18. Eriş H, Havlioğlu S, Küçüközkan Y, Özmen S. SURIYELi MÜLTECI KAMPLARININ BULUNDUĞU ILÇELERDE ÇALIŞAN HEMŞIRE VE EBELERIN TÜKENMIŞLIK SEVIYESI: ŞANLIURFA ÖRNEĞi. THE BURNOUT LEVELS OF NURSES AND MIDWIVES WORKING IN THE DISTRICTS LOCATED NEAR CAMPS OF SYRIAN REFUGEES: CASE OF SANLIURFA. Article in Turkish. Uluslararası Sağlık Yönetimi ve Stratejileri Araştırma Dergisi. 2017;3(3):326339. Accessed May 15, 2021. https://dergipark.org.tr/ en/pub/usaysad/issue/33254/370199

19. Aslan M, Doğan S. DIŞSAL MOTIVASYON, IÇSEL MOTIVASYON VE PERFORMANS ETKILEŞIMINE KURAMSAL BIR BAKIŞ. A THEORETICAL VIEW OF EXTRINSIC MOTIVATION, INTRINSIC MOTIVATION AND PERFORMANCE INTERACTION. Article in Turkish. Süleyman Demirel Üniversitesi Vizyoner Dergisi. 2020;11(26):291-301. doi:10.21076/vizyoner.638479

20. İnce NB, Şahin AE. Maslach Tükenmişlik EnvanteriEğitimci Formu'nu Türkçe'ye Uyarlama Çalışması. The Adaptation Study of Maslach Burnout InventoryEducators Survey to Turkish. Article in Turkish. Eğitimde ve Psikolojide Ölçme ve Değerlendirme Dergisi. 2015;6(2);385-399. Accessed May 15, 2021. https:// dergipark.org.tr/tr/pub/epod/issue/27317/287603 
21. BECK AT, WARD CH, MENDELSON M, MOCK J, ERBAUGH J. An inventory for measuring depression. Arch Gen Psychiatry. 1961;4(6):561-571. doi:10.1001/archpsyc.1961.01710120031004

22. Hisli NS. BECKDEPRESYONENVRANTERININÜNIVERSITE ÖĞRENCILERI içiN GEÇERLiĞi, GÜVENIRLiĞi. The validity and reliability of Beck Depression Inventory for university students. Article in Turkish. Türk Psikoloji Dergisi. 1989;7(23),3-13. Accessed May 15, 2021. https:// www.psikolog.org.tr/tr/yayinlar/dergiler/1031828/ tpd1300443319890000m000366.pdf

23. Maslach C, Jackson SE. The measurement of experienced burnout. Journal of Occupational Behavior.1981;2(2):99-113. doi:10.1002/job.4030020205

24. Ergin C. Doktor ve Hemşirelerde Tükenmişlik ve Maslach Tükenmişlik Ölçeğinin Uyarlanması. Burnout and Adaptation of Maslach Burnout Scale in Doctors and Nurses. In: Bayraktar R, Dağ, İ, eds. VII. Ulusal Psikoloji Kongresi Bilimsel Çalışmaları: 22-25 Eylül 1992, Ankara. 7th National Psychology Congress Scientific Studies Handbook: 22-25 September 1992, Ankara, Hacettepe University. Book in Turkish. Turk Psikologlar Derneği Yayını; 1992:143-154

25. Davis SA. An Organic Problem-Solving Method of Organizational Change. J Appl Behav Sci. 1967;3(1):321. doi:10.1177/002188636700300101

26. Özdayı N. Resmi ve Özel Liselerde Çalışan Öğretmenlerin İş Tatmin Düzeylerinin Karşılaştırılması. Comparison of Job Satisfaction Levels of Public and Private High School Teachers. Article in Turkish. Marmara Üniversitesi Atatürk Eğitim Fakültesi Eğitim Bilimleri Dergisi. 1991;3(3):221-235. Accessed May 15, 2021. https:// dergipark.org.tr/en/pub/maruaebd/issue/352/2348

27. Uçucu G. Aydın ilindeki ebelerin örgütsel bağlılı̆̆ iş doyumu ve etkileyen faktörler. Organizational commitment job satisfaction and factors affecting the obstetrics in Aydin province. Master's thesis. Thesis in Turkish. Adnan Menderes University; 2019. Accessed May 15, 2021. https://tez.yok.gov.tr/UlusalTezMerkezi/ tezDetay.jsp? id=GHwpEnGOm1EdU9Jk4PuNAQ\&no= hJFyTtqNBqhHveNQmHQGwQ

28. Başkaya Y. Türkiye'deki Ebelerin Mesleki Aidiyeti ve Tükenmişlik Düzeyleriyle Illişkisi. The Relationship Between Turkish Midwives' Professional Belonging and Burnout Levels. Dissertation. Dissertation in Turkish. Eskişehir Osmangazi University; 2018. Accessed May 15, 2021. https://toad.halileksi.net/sites/default/ files/pdf/ebelik-aidiyet-olcegi-toad.pdf

29. Kundak Z, Üzel Taş $H$, Keleş A, Eğicioğlu H. Bir Üniversite Hastanesinde Hemşirelik Mesleğinde İş Tatmini ve Motivasyon. Job Satisfaction and Motivation in Nursing Profession. Article in Turkish. Kocatepe Tıp Dergisi. 2015;16(1):1-10. Acccessed May 15, 2021. https://dergipark.org.tr/en/pub/kocatepetip/ issue/17400/182153

30. Hunter B, Fenwick J, Sidebotham M, Henley J. Midwives in the United Kingdom: Levels of burnout, depression, anxiety and stress and associated predictors. Midwifery. 2019;79:102526. doi:10.1016/j.midw.2019.08.008
31. Creedy DK, Sidebotham M, Gamble J, Pallant J, Fenwick J. Prevalence of burnout, depression, anxiety and stress in Australian midwives: a cross-sectional survey. BMC Pregnancy Childbirth. 2017;17(1):13. doi:10.1186/s12884-016-1212-5

32. Tekin Kaya N, Bilgin S. Çankırı II Merkezinde Birinci Basamak Sağlık Kuruluşlarında Çalışan Ebe ve Hemşirelerdelş Doyumu Düzeyi Ve Etkileyen Faktörlerin Değerlendirilmesi. Article in Turkish. Hacettepe Üniversitesi Sağlık Bilimleri Fakültesi Dergisi. 2015;1(Suppl 1):1-24. Accessed May 15, 2021. https:// dergipark.org.tr/en/pub/husbfd/issue/7891/103825

33. Erdogan M. The impact of some characteristics of newborn and child intensive care nurses on motivation levels of job satisfaction. Koc University Institute of Health Sciences, Master's Thesis, Istanbul, 2017.

34. Ünver $H$, Aksoy Derya $Y$, Uçar T. DOĞUMHANEDE ÇALIŞAN EBELERDE IŞE BAĞLI GERGINLIK DÜZEYI ILE TÜKENMIŞLIK, ÖRGÜTSEL BAĞLILIK VE ÖRGÜTSEL ADALET DÜZEYLERI ARASINDAKI ILIŞKI. Relationship between Work-Related Tension Level and Burnout, Organizational Commitment and Justice Levels of the Midwifes Working in Delivery Units. Article in Turkish. İnönü Üniversitesi Sağlık Hizmetleri Meslek Yüksek Okulu Dergisi. 2020;8(3):893-905. doi:10.33715/inonusaglik.747322

35. Taycan O, Kutlu L, Çimen S, Aydin N. Bir üniversite hastanesinde çalışan hemşirelerde depresyon ve tükenmişlik düzeyinin sosyodemografik özelliklerle ilişkisi. The relationship between depression and burnout level and sociodemographic characteristics in nurses working in a university hospital. Article in Turkish. Anadolu Psikiyatri Dergisi. 2006;7(2):100-108. Accessed May 15, 2021. https://app.trdizin.gov.tr/ publication/paper/detail/TIRrMk56RXg

\section{CONFLICTS OF INTEREST}

The authors have completed and submitted the ICMJE Form for Disclosure of Potential Conflicts of Interest and none was reported.

\section{FUNDING}

There was no source of funding for this research.

\section{ETHIGAL APPROVAL AND INFORMED CONSENT}

Ethical approval for the study was obtained from Inonu University Medical Sciences Scientific Research and Publication Ethics Committee (Decision No: 2020/1160). An institutional approval was also obtained from the Provincial Health Directorate of the relevant province, before initiating the research. Participation was voluntarily, and participating midwives were informed for the aims of the research at the beginning of the questionnaire.

\section{DATA AVAILABILITY}

Data sharing is not applicable to this article as no new data were created.

\section{PROVENANGe ANd PEER REVIEW}

Not commissioned; externally peer reviewed. 